\title{
STRATEGI PENGEMBANGAN DTW PANTAI DIAMOND DI DUSUN PELILIT, DESA PEJUKUTAN, NUSA PENIDA, KLUNGKUNG, BALI
}

\author{
Agnela Saneta Listiowati \\ Universitas Udayana \\ Email: agnelsArch@gmail.com \\ Agung Suryawan Wiranatha \\ Pusat Unggulan Pariwisata \\ Email: balitruly@yahoo.com \\ I Gusti Ayu Oka Suryawardani \\ Universitas Udayana \\ Email: gungdani@gmail.com
}

\begin{abstract}
Diamond Beach is located at Pelilit Village, Pejukutan Village, Nusa Penida District. This tourist attraction was developed since 2014. Even though it have been developed since five years ago, there is still bad perception from local community about the components at Diamond Beach, in specific about amenity, accessibility, and human resource. Those local community perception contrasts with the perception of tourists that visited Diamond Beach, which they have good perception of all destination components in Diamond Beach. This research used qualitative descriptive approach that concerned about the perception of tourist and local community towards destination component at Diamond Beach. All perceptions and collected data using triangulation were used to identify internal and external environment condition at Diamond Beach. Result of internal and external factor analysis at Diamond Beach were both in medium condition. Then, the proper grand strategy to be applied in next level is keeping up and maintaining without changing the strategy that has been used before. This grand strategy is stressing more about product and service development, also market penetration.
\end{abstract}

Keywords: perception, development strategy, tourist attraction 


\section{Pendahuluan}

Pengembangan sistem kepariwisataan bertujuan untuk melaksanakan rencana pembangunan kepariwisataan dengan memperhatikan keanekaragaman, keunikan, dan kekhasan budaya dan alam, serta kebutuhan manusia untuk berwisata yang didasarkan pada asas manfaat, kekeluargaan, adil dan merata, keseimbangan, kemandirian, kelestarian, partisipatif, berkelanjutan, demokrasi, kesetaraan, dan kesatuan pembangunan kepariwisataan (Pemerintah Republik Indonesia, 2009). Suatu Daya Tarik Wisata (DTW) akan mengalami perkembangan sistem kepariwisataan apabila sebelumnya telah dilakukan aktivitas pariwisata pada DTW tersebut (Hidayat, 2011).

Pengembangan Nusa Penida sebagai salah satu tujuan wisata bahari terbaik Pulau Bali dikembangkan melalui tujuh blok Kawasan Efektif Pariwisata (KEP), yakni KEP Lembongan, KEP Jungutbatu, KEP Ceningan, KEP Sakti-Toyapakeh, KEP Sakti-Bunga Mekar, KEP Suana-Pejukutan, serta KEP Batununggul (Pemerintah Kabupaten Klungkung, 2013). PAD tertinggi berasal dari KEP Jungutbatu, sebesar Rp 341.940.000,00, dan PAD terendah berasal dari KEP Suana-Pejukutan, sebesar Rp 7.459.000,00 (BPS Kabupaten Klungkung, 2018).

Kebijakan pengembangan pariwisata berkelanjutan yang telah ditetapkan oleh World Tourim Organization (WTO) menitikberatkan pada tiga hal, yakni keberlanjutan alam, sosial dan budaya, serta ekonomi (Yulianti, n.d.). Meski demikian, menurut Yulianti, perkembangan sistem kepariwisataan Bali tidak hanya memberikan dampak positif pada PAD, namun juga memberikan dampak negatif berupa pencemaran lingkungan, kemacetan lalu lintas, kerusakan lingkungan, dan pengalihan fungsi lahan.

BPS Kabupaten Klungkung (2018) mencatat, Desa Lembongan di Kecamatan Nusa Penida yang masuk dalam KEP Lembongan merupakan penyumbang PAD tertinggi ke tiga setelah KEP Jungutbatu dan KEP Toyapakeh, yakni sebesar Rp 
49.300.000,00. Berbagai fenomena yang muncul akibat perkembangan kepariwisataan di Desa Lembongan adalah terjadinya kerusakan tata lingkungan dan keruangan di desa ini (Santhyasa, n.d.). Berbagai akomodasi pariwisata yang dibangun tanpa ijin berdampak pada ketidaksesuaian peruntukan tata guna lahan serta terjadinya kasus pelanggaran sempadan pantai. Dampaknya terhadap lingkungan adalah ancaman kehidupan habitat laut dan budidaya rumput laut di selat perairan antara Pulau Nusa Ceningan dan Pulau Nusa Lembongan karena limbah yang dihasilkan dari berbagai akomodasi tersebut dialirkan menuju laut. Dampaknya terhadap masyarakat lokal adalah terjadi marginalisasi dalam mempertahankan salah satu mata pencaharian sebagai petani rumput laut (Santhyasa, n.d.).

Desa Pejukutan adalah salah satu desa yang tergabung dalam KEP SuanaPejukutan dan merupakan penyumbang PAD terendah di Kecamatan Nusa Penida, yakni sebesar Rp 1.247.000,00 (BPS Kabupaten Klungkung, 2018). Desa Pejukutan memiliki tiga DTW utama yang seluruhnya berlokasi di Dusun Pelilit, yakni DTW Pantai Atuh, DTW Pantai Diamond dan DTW Rumah Pohon Molenteng. Dari ke tiga DTW tersebut, DTW Pantai Diamond merupakan DTW baru yang baru dibuka pada akhir tahun 2018 lalu dan terbukti mampu meningkatkan jumlah kunjungan wisatawan. Rata-rata jumlah kunjungan wisatawan diawal pembukaan akses menuju DTW Pantai Diamond (akhir tahun 2018) adalah 50 wisatawan perhari meningkat menjadi 250 wisatawan perhari pada Bulan April 2019.

Meningkatnya jumlah kunjungan wisatawan yang sangat pesat di Dusun Pelilit dapat menjadi peluang bagi Desa Pejukutan untuk meningkatkan PAD melalui pengembangan sistem kepariwisataan, terutama di DTW Pantai Diamond yang merupakan magnet baru bagi wisatawan. Dengan mempelajari fenomena dampak perkembangan kepariwisataan yang terjadi di Desa Lembongan, Desa Pejukutan memiliki kesempatan untuk mengembangkan sistem kepariwisataan yang lebih sistematis, terencana, terpadu, berkelanjutan, dan bertanggung jawab 
terhadap nilai-nilai agama, budaya yang hidup dalam masyarakat, kelestarian dan mutu lingkungan hidup, serta kepentingan nasional.

Keberhasilan pengembangan suatu DTW bergantung pada keinginan wisatawan untuk mengunjungi DTW tersebut, tanpa kehadiran wisatawan pengembangan suatu DTW akan dinilai gagal karena tidak mampu menarik minat wisatawan untuk berkunjung. Persepsi wisatawan merupakan hal penting dalam pengembangan suatu destinasi, sebab persepsi wisatawan akan mempengaruhi keberhasilan pengembangan DTW, baik mengenai apa yang diminati, diinginkan dan diharapkan oleh seorang wisatawan terhadap suatu destinasi menjadi sangat penting artinya dalam kaitannya dengan promosi produk destinasi.

Dampak perkembangan pariwisata akan berpengaruh pada persepsi masyarakat terhadap perkembangan pariwisata di daerahnya. Persepsi masyarakat terhadap dampak perkembangan akan berpengaruh pada kualitas keamanan dan kenyamanan wisatawan pada saat mengunjungi suatu DTW. Perbedaan nilai sosial dan kondisi eknomi antara wisatawan yang berkunjung ke DTW Pantai Atuh dengan masyarakat lokal Dusun Pelilit akan mempengaruhi terbentuknya persepi dan menjadi tantangan dalam menentukan strategi pengembangan DTW Pantai Diamond di masa yang akan datang. Pemahaman mengenai persepsi wisatawan terhadap komponen destinasi DTW Pantai Diamond dan persepsi masyarakat terhadap pengembangan komponen destinasi DTW Pantai Diamond dapat digunakan sebagai acuan dalam menentukan strategi pengembangan DTW Pantai Diamond secara khusus dan Dusun Pelilit secara umum di masa yang akan datang. 


\section{Teori dan Konsep}

\section{Persepsi}

Persepsi adalah proses kognitif yang digunakan oleh individu untuk menafsirkan dan memahami dunia sekitarnya, persepsi adalah proses pemberian arti terhadap lingkungan oleh individu dimana pemberian arti ini akan berbeda dari masing-masing individu meskipun pada obyek yang sama (Gibson, et.al., (1989) dalam Noordien, n.d.).

Gibson, et.al., (1989) menyatakan, persepsi dipengaruhi oleh dua faktor, faktor internal dan eksternal (Noordien, n.d.). Faktor internal yang mempengaruhi persepsi individu adalah fisiologis (alat indra); perhatian (energi yang dikeluarkan); minat (perceptual vigilance); kebutuhan yang searah; pengalaman dan ingatan; serta suasana hati. Faktor eksternal yang mempengaruhi persepsi individu adalah ukuran dan penempatan obyek; warna dan obyek; keunikan dan kekontrasan; intensitas dan kekuatan; serta motion (gerakan).

Robbins (2001) menyebutkan, faktor-faktor yang berperan dalam pembentukan persepsi adalah karakteristik pelaku persepsi (pemersepsi); target/obyek persepsi (gerakan, keunikan, bentuk, ukuran); serta situasi (waktu, keadaan tempat kerja, keadaan sosial) (Noordien, n.d.). Pareek (1984) menyatakan, faktor yang menyebabkan perbedaan persepsi adalah perhatian, kebutuhan, kesediaan, serta sistem nilai (Noordien, n.d.).

\section{Komponen Produk Wisata}

World Tourism Organization (WTO) menyebutkan, terdapat enam komponenkomponen pembentuk kepariwisataan, yakni atraksi, amenitas, aksesibilitas, SDM, citra, dan harga (Tegar, 2018). Atraksi merupakan komponen utama kepariwisataan yang akan memotivasi wisatawan dalam memilih lokasi wisata; amenitas merupakan layanan fasilitas pendukung aktivitas kepariwisataan di lokasi wisata; 
aksesibilitas merupakan daya dukung sistem transportasi untuk mencapai lokasi wisata; SDM merupakan aset yang dimiliki lokasi wisata untuk membentuk pengalaman wisatawan selama melakukan kunjungan wisata; citra merupakan komponen penting dalam menentukan minat wisatawan untuk berkunjung; harga merupakan komponen yang akan selalu dipengaruhi oleh kualitas pelayanan dari ke lima komponen pembentuk kepariwisataan lainnya.

\section{Konsep dan strategi pengembangan DTW}

Menurut Sunaryo (2013), pengembangan kepariwisataan merupakan suatu proses terencana untuk mengubah kondisi kepariwisataan yang dinilai kurang baik menuju situasi yang dianggap lebih baik atau lebih diinginkan. Pengembangan kepariwisataan harus dilandaskan pada satu paradigma atau model pembangunan kepariwisataan yang sama antar stakeholder agar tidak berjalan menurut intuisi, penafsiran dan kepentingannya sendiri.

Empat kaidah yang harus menjadi roh keberpihakan suatu model dan strategi perencanaan pembangunan kepariwisataan adalah (1) keberpihakan terhadap visi, misi, tujuan, dan sasaran prioritas tertentu yang dirumuskan oleh pihak otoritas berwenang; (2) fleksibelitas pertumbuhan pembangunan kepariwisataan sesuai dengan dinamika perkembangan sosial, ekonomi, budaya, dan politik secara nasional maupun internasional; (3) mengantisipasi keberlanjutan pembangunan kepariwisataan untuk generasi yang akan datang; serta (4) mengantisipasi dan responsif dalam merencanakan pembangunan kepariwisataan sesuai dinamika situasi dan realitas kenyataan diseluruh wilayah yang berkaitan (Sunaryo, 2013).

Konsep blue economy merupakan jawaban dari suatu sistem perekonomian dunia yang cenderung mengeksploitasi dan menjadi penyebab kerusakan lingkungan, dimana konsep ini tidak hanya mengutamakan pertumbuhan ekonomi dari suatu proses pengembangan tetapi juga memperhatikan keberlanjutan ekologi dan sosialnya (Tegar R \& Gurning, 2018). 


\section{Kepariwisataan berwawasan lingkungan}

Sunaryo (2013) menggambarkan empat variasi kemungkinan dampak dari empat kuadran hubungan antara kepariwisataan dan lingkungan. Dampak yang paling ideal adalah symbiosis mutualistic, dimana kepariwisataan memperoleh dukungan positif dari lingkungan, dan sebaliknya. Dampak yang ekstrim negatif adalah dispolation, dimana lingkungan tidak menghendaki kehadiran kepariwisataan dan kepariwisataan menimbulkan dampak negatif terhadap lingkungan setempat. Tiga indikator yang dapat digunakan untuk mengukur keberhasilan pembangunan kepariwisatan berwawasan lingkungan adalah (1) positive socio-economic change; (2) does not undermine the ecological and social systems; serta (3) integrated policy, planning, and social learning processes.

Aktivitas pariwisata global yang lebih mengedepankan perolehan devisa merupakan ancaman terhadap pengetahuan dan hak intelektual masyarakat lokal serta kerusakan lingkungan. Sehingga, lahirlah konsep pariwisata berkelanjutan yang menggabungkan pendekatan ekonomi dengan kelestarian alam yang bertujuan untuk meraih kesuksesan jangka panjang melalui penyelarasan diri terhadap lingkungan serta menjauhkan diri dari sifat individualisme (Rogers, 2001 dalam Jackson, et al, 2011).

\section{Konsep triple bottom line (TBL)}

Konsep TBL atau Formula 3P memiliki tiga pilar utama yang digunakan untuk mengukur kesuksesan suatu perusahaan, yakni people (soisal), profit (ekonomi), dan planet (lingkungan) (Elkington (1997) dalam Rosyidah, 2017; Neviana, 2010). Tujuan utamanya adalah untuk meraih sistem yang berkelanjutan (Brooks, 2013). Manfaat dari diterapkannya konsep ini adalah meningkatkan pendapatan, semangat kerja karyawan, pengurangan biaya operasional (konsumsi energi dan air), serta kesetiaan pelanggan (Brooks, 2013). 


\section{Metode Penelitian}

Penelitian ini menggunakan pendekatan penelitian kualitatif Penelitian ini dilakukan di DTW Pantai Diamond, Dusun Pelilit, Desa Pejukutan, Kecamatan Nusa Penida, yang dimulai pada bulan April hingga Juli 2019. Jenis data yang digunakan adalah kualitatif dan kuantitatif, sumber data berasal dari data primer dan sekunder yang dikumpulkan dengan metode triangulasi, yaitu observasi, wawancara, survey, dan studi dokumen. Instrumen yang digunakan adalah check list, daftar pertanyaan, angket, kamera, dan recorder. Hasil analisis data disajikan secara deskriptif interpretatif.

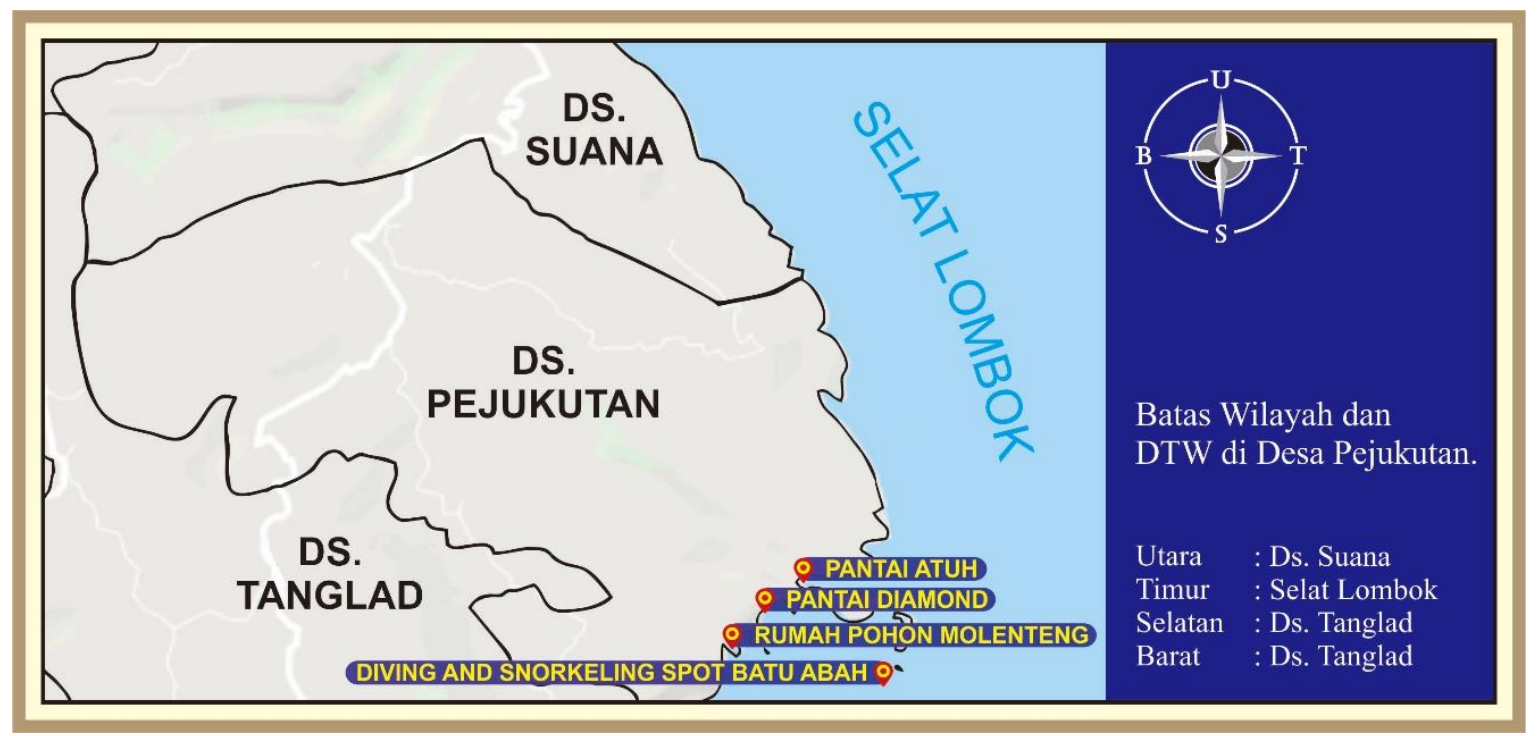

Gambar 1. Batas Wilayah dan DTW di Desa Pejukutan

Sumber: Google Maps dengan penambahan keterangan oleh Peneliti, 2019

Observasi dilakukan pada obyek manusia, alam maupun kebudayaan di DTW Pantai Diamond secara khusus dan Dusun Pelilit secara umum. Wawancara dilakukan dengan teknik purposive sampling dan snowball sampling, yaitu pengelola (sebagai informan kunci), pemerintah dan pengusaha. Survey dilakukan dengan menyebarkan angket kepada wisatawan dan masyarakat. Responden wisatawan dipilih dengan teknik incidental sampling kepada 130 wisatawan yang berusia diatas 17 tahun. Responden masyarakat dipilih dengan teknik purposive sampling kepada 30 
masyarakat yang dianggap memperoleh dampak dari pengembangan pariwisata DTW Pantai Diamond.

Analisis data dalam penelitian ini menggunakan teknik analisis statistik deskriptif, analisis Matriks IFAS, EFAS, IE, serta SWOT. Analisis statistik deskriptif digunakan untuk mengetahui rata-rata penilaian wisatawan dan masyarakat berdasarkan enam komponen destinasi di DTW Pantai Diamond. Analisisi Matriks IFAS dan EFAS digunakan untuk mengetahui pengaruh faktor internal dan eksternal DTW Pantai Diamond. Analisis Matriks IE digunakan untuk mengetahui kedudukan (posisi) pengembangan yang telah dilakukan di DTW Pantai Diamond serta menentukan grand strategi pengembangan yang tepat berdasarkan kedudukan faktor internal dan eksternalnya. Analisis SWOT digunakan untuk menyusun empat set kemungkinan alternatif strategi berdasarkan faktor kekuatan, kelemahan, peluang, serta ancaman yang dimiliki DTW Pantai Diamond.

\section{Hasil dan Pembahasan}

\section{Persepsi wisatawan terhadap DTW Pantai Diamond}

Wisatawan sebagai responden didominasi oleh wisatawan nusantara yang datang secara pribadi dengan menggunakan mobil. Jenis kelamin wisatawan didominasi oleh wanita dengan rentang usia antara 25 - 34 tahun dan bekerja sebagai karyawan. Kebanyakan wisatawan merupakan pengunjung yang baru pertama kali datang dengan sumber informasi terbanyak berasal dari media sosial. 


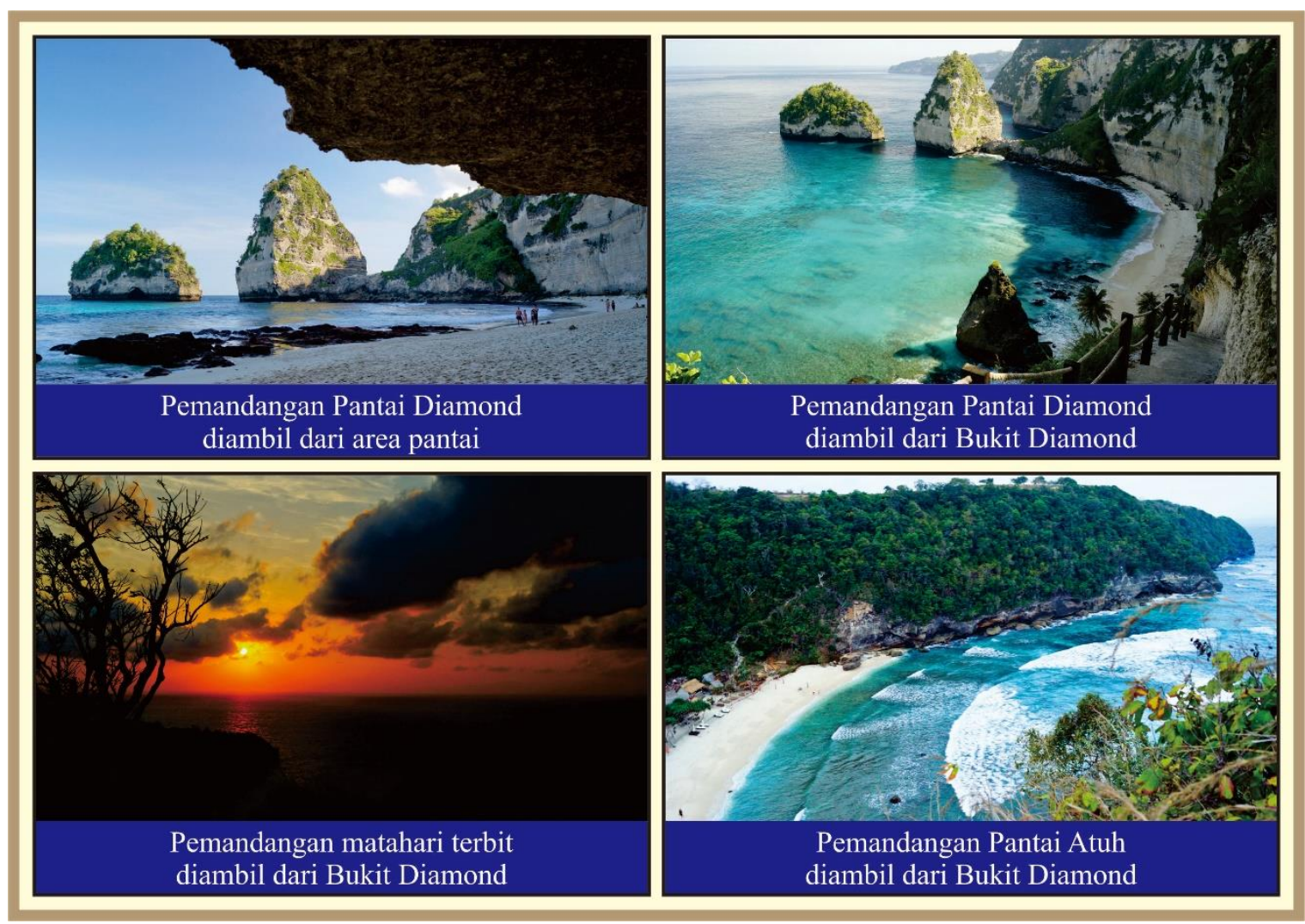

Gambar 2. Kualitas Pemandangan Alam DTW Pantai Diamond Sumber: Dokumentasi Peneliti, 2019

Persepsi terbaik wisatawan adalah pada variabel citra. Tingginya penilaian wisatawan ini dipengaruhi oleh pengelolaan yang maksimal terhadap indikator ciri khas/keunikan, kualitas kebersihan lingkungan, kualitas udara, serta keramahan masyarakat terhadap kehadiran wisatawan. Akan tetapi terdapat satu indikator yang mendapat penilaian buruk dari responden, yaitu pada indikator kualitas keselamatan wisatawan. Persepsi terburuk wisatawan adalah pada variabel aksesibilitas. Indikator yang memperburuk penilaian wisatawan terhadap variabel aksesibilitas adalah kualitas jalan atau infrastruktur menuju DTW. Hal ini menunjukkan bahwa kualitas akses menuju DTW Pantai Diamond belum mampu memberikan kenyamanan kepada wisatawan pada saat berkunjung ke DTW Pantai Diamond. 


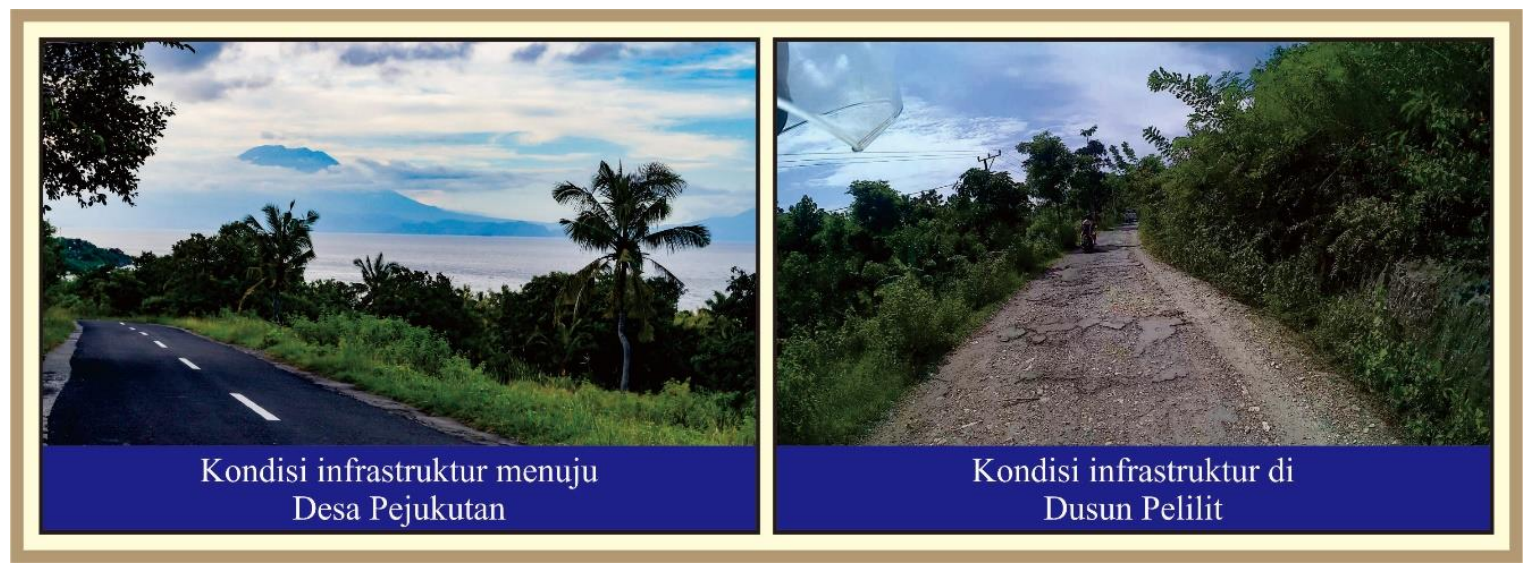

Gambar 3. Kondisi Infrastruktur Menuju Desa Pejukutan dan di Dusun Pelilit Sumber: Dokumentasi Peneliti, 2019

\section{Persepsi masyarakat terhadap pengembangan DTW Pantai Diamond}

Masyarakat sebagai responden penelitian didominasi oleh masyarakat yang berasal dari Desa Pejukutan dan bekerja sebagai SDM Pariwisata di Dusun Pelilit, berjenis kelamin pria dengan rentang usia antara 35 - 49 tahun.

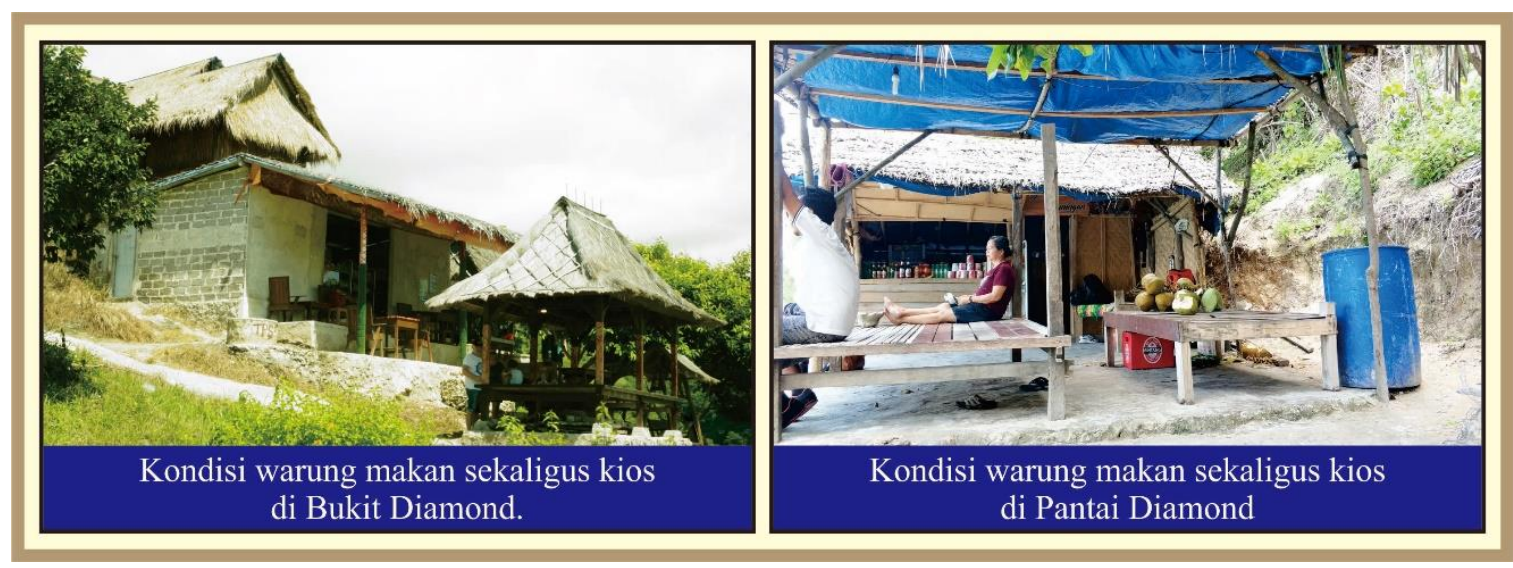

Gambar 4. Fasilitas Warung Makan dan Kios di DTW Pantai Diamond Sumber: Dokumentasi Peneliti, 2019

Variabel atraksi memperoleh rata-rata penilaian tertinggi dari masyarakat. Dari empat indikator yang digunakan menunjukkan potensi DTW Pantai Diamond telah dikembangkan dengan maksimal dan pengembangan yang dilakukan saat ini tidak menimbulkan banyak dampak negatif terhadap kelestarian lingkungan, kebudayaan masyarakat, serta aktivitas kebudayaan masyarakat. Vriabel amenitas 
DTW Pantai Diamond masih memperoleh penilaian terendah dari masyarakat, hal ini menunjukkan bahwa pengelolaan fasilitas pendukung kepariwisataan masih belum dikelola dengan baik, sehingga perlu dilakukan strategi pengembangan yang lebih baik sebagai upaya untuk menyediakan fasilitas yang lebih memadahi sesuai dengan ciri arsitektur tradisional kebudayaan Bali.

\section{Analisis Matriks IFAS dan EFAS}

Faktor internal yang digunakan pada analisis matriks IFAS adalah sebanyak 23 faktor, dan memperoleh nilai 2,425. Angka tersebut menunjukkan bahwa faktor internal lingkungan DTW Pantai Diamond masuk dalam kategori sedang. Faktor internal ini terdiri dari sembilan faktor kekuatan dan 14 faktor kelemahan (lihat Tabel 1).

Faktor eksternal yang digunakan pada analisis matriks EFAS adalah sebanyak 19 faktor, dan memperoleh nilai 2,670. Angka tersebut menunjukkan bahwa faktor eksternal lingkungan masuk dalam kategori sedang. Faktor eksternal ini terdiri dari 13 faktor peluang dan enam faktor ancaman (lihat Tabel 2). 
Tabel 1. Analisis Matriks IFAS DTW Pantai Diamond

\begin{tabular}{|c|c|c|c|c|c|}
\hline \multicolumn{2}{|c|}{ Faktor Strategi Internal } & \multirow{2}{*}{$\frac{\text { Bobot }}{0,065}$} & \multirow{2}{*}{$\begin{array}{l}\text { Rating } \\
4\end{array}$} & \multirow{2}{*}{$\frac{\text { Nilai }}{0,260}$} & \multirow{2}{*}{$\begin{array}{l}\text { Komentar } \\
\text { Kekuatan }\end{array}$} \\
\hline 1) & Kualitas lokal fotografi & & & & \\
\hline 2) & Keragaman event kepariwisataan & 0,040 & 1 & 0,040 & Kelemahan \\
\hline 3) & Faktor keselamatan & 0,045 & 2 & 0,090 & Kelemahan \\
\hline 4) & Stabilitas ombak laut & 0,035 & 2 & 0,070 & Kelemahan \\
\hline 5) & Papan penunjuk informasi & 0,035 & 2 & 0,070 & Kelemahan \\
\hline 6) & Desain bangunan khas Bali & 0,045 & 1 & 0,045 & Kelemahan \\
\hline 7) & Jaringan listrik & 0,040 & 4 & 0,160 & Kekuatan \\
\hline 8) & Jaringan internet & 0,035 & 1 & 0,035 & Kelemahan \\
\hline 9) & Aktivitas pembakaran sampah & 0,045 & 1 & 0,045 & Kelemahan \\
\hline 10) & $\begin{array}{l}\text { Pemanfaatan area Pantai } \\
\text { Diamond }\end{array}$ & 0,045 & 2 & 0,090 & Kelemahan \\
\hline 11) & Stabilitas Tebing Diamond & 0,045 & 4 & 0,180 & Kekuatan \\
\hline 12) & Waktu tempuh & 0,035 & 3 & 0,105 & Kekuatan \\
\hline 13) & Area parkir & 0,035 & 2 & 0,070 & Kelemahan \\
\hline 14) & Sikap masyarakat & 0,060 & 4 & 0,240 & Kekuatan \\
\hline 15) & Minat usaha masyarakat & 0,035 & 3 & 0,105 & Kekuatan \\
\hline 16) & Kompetensi SDM Pariwisata & 0,045 & 2 & 0,090 & Kelemahan \\
\hline 17) & Jalur pedestrian & 0,050 & 3 & 0,150 & Kekuatan \\
\hline 18) & Kebiasaan masyarakat & 0,050 & 4 & 0,200 & Kekuatan \\
\hline 19) & Keberadaan tanaman & 0,035 & 2 & 0,070 & Kelemahan \\
\hline 20) & Ketersediaan penjaga pantai & 0,040 & 1 & 0,040 & Kelemahan \\
\hline 21) & Ketersediaan petugas kebersihan & 0,055 & 1 & 0,055 & Kelemahan \\
\hline 22) & Fasilitas tempat makan & 0,045 & 3 & 0,135 & Kekuatan \\
\hline 23) & Fasilitas toilet umum & 0,040 & 2 & 0,080 & Kelemahan \\
\hline TO & TAL & 1,000 & & 2,425 & \\
\hline
\end{tabular}

Sumber: Peneliti, 2019 
Tabel 2. Analisis Matriks EFAS DTW Pantai Diamond

\begin{tabular}{|c|c|c|c|c|c|}
\hline \multicolumn{2}{|c|}{ Faktor Strategi Internal } & \multirow{2}{*}{$\frac{\text { Bobot }}{0,045}$} & \multirow{2}{*}{$\begin{array}{l}\text { Rating } \\
3\end{array}$} & \multirow{2}{*}{$\begin{array}{l}\text { Nilai } \\
0,135\end{array}$} & \multirow{2}{*}{$\begin{array}{l}\text { Komentar } \\
\text { Peluang }\end{array}$} \\
\hline 1) & KEP Suana-Pejukutan & & & & \\
\hline 2) & Pusat DTW & 0,065 & 4 & 0,260 & Peluang \\
\hline 3) & $\begin{array}{l}\text { Proyek The Atuh Beach Resort } \mathcal{E} \\
\text { Spa }\end{array}$ & 0,035 & 1 & 0,035 & Ancaman \\
\hline 4) & Tari Baris Jangkang & 0,050 & 4 & 0,200 & Peluang \\
\hline 5) & Kain Tenun Rangrang & 0,050 & 4 & 0,200 & Peluang \\
\hline 6) & Kebersihan lingkungan & 0,060 & 1 & 0,060 & Ancaman \\
\hline 7) & Fasilitas photo spot & 0,055 & 3 & 0,165 & Peluang \\
\hline 8) & Hubungan antar stakeholders & 0,045 & 2 & 0,090 & Ancaman \\
\hline 9) & Dukungan investor & 0,065 & 3 & 0,195 & Peluang \\
\hline 10) & Ketersediaan air bersih & 0,055 & 1 & 0,055 & Ancaman \\
\hline 11) & Fasilitas penginapan & 0,060 & 3 & 0,180 & Peluang \\
\hline 12) & $\begin{array}{l}\text { Akses \& ketersediaan alat } \\
\text { transportasi }\end{array}$ & 0,060 & 3 & 0,180 & Peluang \\
\hline 13) & Kondisi infrastruktur & 0,055 & 2 & 0,110 & Peluang \\
\hline 14) & Papan informasi penunjuk arah & 0,045 & 2 & 0,090 & Ancaman \\
\hline 15) & Harga produk dan jasa & 0,055 & 1 & 0,055 & Ancaman \\
\hline 16) & Fasilitas toko oleh-oleh & 0,050 & 3 & 0,150 & Peluang \\
\hline 17) & Pelatihan SDM Pariwisata & 0,060 & 4 & 0,240 & Peluang \\
\hline 18) & Promosi & 0,045 & 3 & 0,135 & Peluang \\
\hline 19) & Pokdarwis & 0,045 & 3 & 0,135 & Peluang \\
\hline TOT & $\mathrm{AL}$ & 1,000 & & 2,670 & \\
\hline
\end{tabular}

Sumber: Peneliti, 2019 


\section{Analisis Matriks IE}

Analisis matriks IFAS dan EFAS memperlihatkan faktor internal dan eksternal lingkungan DTW Pantai Diamond berada pada kategori sedang. Apabila ditarik garis pada matriks IE, kondisi internal dan eksternal lingkungan DTW Pantai Diamond masuk dalam sel $\mathrm{V}$, yaitu pertahankan dan pelihara (tanpa mengubah arah strategi pengembangannya).

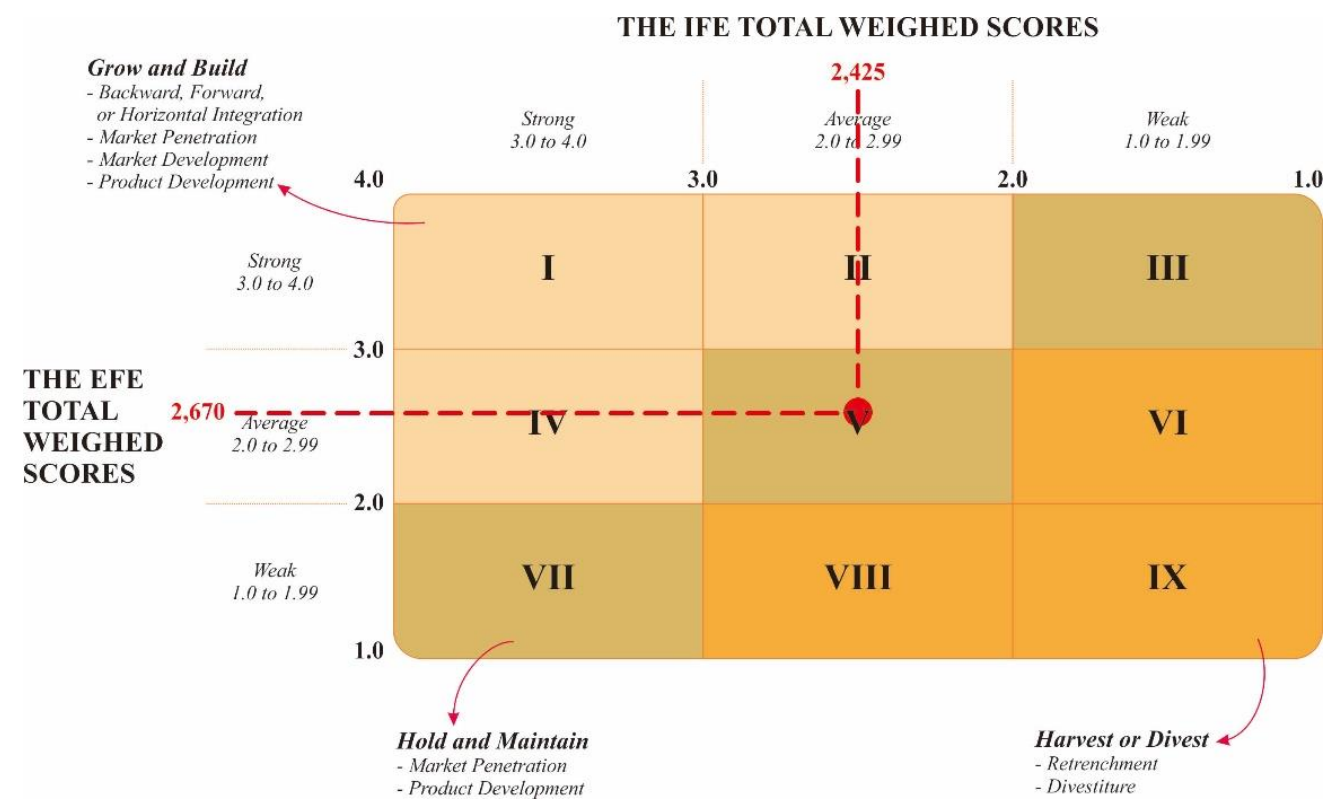

Gambar 5. Analisis Matriks IE DTW Pantai Diamond Sumber: David, et.al., (2017) diadopsi oleh Peneliti, 2019

Grand strategy perkembangan yang tepat untuk diterapkan di DTW Pantai Diamond pada tahap selanjutnya adalah lebih menekankan pada upaya pengembangan produk dan jasa serta melakukan penetrasi pasar (pemasaran), termasuk didalamnya adalah mengubah, menambah atau merumuskan kembali sifat-sifat pokok yang sudah ada dalam segi corak, merk dan kualitasnya.

\section{Analisis Matriks SWOT}

Sel V menunjukkan bahwa tahap pengembangan DTW Pantai Diamond berada pada kategori growth and stability atau tumbuh dan pertahankan, tanpa mengubah arah strategi yang telah ditetapkan. Sel V lebih menekankan pada 
pengembangan produk dan jasa serta melakukan promosi produk wisata yang lebih agrasif (penetrasi pasar). Selain itu, proses penemuan ide untuk barang dan jasa dapat dilakukan oleh pengelola DTW Pantai Diamond untuk meraih kesuksesan pengembangan-termasuk mengubah, menambah atau merumuskan kembali sebagian dari produk yang sudah ada dari segi corak, merk dan kualitas.

Tabel 3. Analisis Matriks SWOT DTW Pantai Diamond

\begin{tabular}{|c|c|c|}
\hline & $\begin{array}{l}\quad \text { KEKUATAN (Strengths) } \\
\text { - Kualitas lokal fotografi } \\
\text { - Jaringan listrik } \\
\text { - Stabilitas Tebing Diamond } \\
\text { - Waktu tempuh } \\
\text { - Sikap masyarakat } \\
\text { - Minat usaha masyarakat } \\
\text { - Jalur pedestrian } \\
\text { - Kebiasaan masyarakat } \\
\text { - Fasilitas tempat makan } \\
\text { - Tari Baris Jangkang } \\
\text { - Kain Tenun Rangrang } \\
\text { - Fasilits photo spot }\end{array}$ & $\begin{array}{l}\text { KELEMAHAN (Weaknesses) } \\
\text { - Keragaman event kepariwisataan } \\
\text { - Faktor keamanan } \\
\text { - Stabilitas ombak laut } \\
\text { - Desain bangunan khas Bali } \\
\text { - Jaringan internet } \\
\text { - Aktivitas pembakaran sampah } \\
\text { - Pemanfaatan area Pantai Diamond } \\
\text { - Area parkir } \\
\text { - Kompetensi SDM Pariwisata } \\
\text { - Keberadaan tanaman } \\
\text { - Ketersediaan penjaga pantai } \\
\text { - Ketersediaan petugas kebersihan } \\
\text { - Fasilitas toilet umum } \\
\text { - Kebersihan lingkungan } \\
\text { - Ketersediaan air bersih } \\
\text { - Harga produk dan jasa }\end{array}$ \\
\hline $\begin{array}{l}\text { PELUANG (Opportunities) } \\
\text { - KEP Suana-Pejukutan } \\
\text { - Pusat DTW } \\
\text { - Dukungan investor } \\
\text { - Fasilitas penginapan } \\
\text { - Akses \& ketersediaan alat transportasi } \\
\text { - Fasilitas toko oleh-oleh } \\
\text { - Pelatihan SDM Pariwisata } \\
\text { - Promosi produk wisata } \\
\text { - Pokdarwis }\end{array}$ & $\begin{array}{l}\text { STRATEGI SO } \\
\text { - Menambah fasilitas photo spot } \\
\text { - Mengembangkan fasilitas kepariwisataan } \\
\text { - Meningkatkan kualitas infrastruktur } \\
\text { dan akses } \\
\text { - Melakukan promosi } \\
\text { - Melakukan sosialisasi dan } \\
\text { membentuk Pokdarwis } \\
\text { - Menciptakan produk souvenir } \\
\text { - Memaksimalkan ragam jenis atraksi wisata }\end{array}$ & $\begin{array}{l}\text { STRATEGI WO } \\
\text { - Menonjolkan arsitektur tradisional Bali } \\
\text { - Memberikan pelatihan kepada } \\
\text { SDM Pariwisata } \\
\text { - Meningkatkan faktor keselamatan }\end{array}$ \\
\hline $\begin{array}{l}\text { ANCAMAN (Threats) } \\
\text { - Proyek The Atuh Beach Resort \& Spa } \\
\text { - Sampah kiriman } \\
\text { - Bencana alam } \\
\text { - Hubungan antar stakeholders } \\
\text { - Kondisi infrastruktur } \\
\text { - Papan informasi penunjuk arah } \\
\text { - Harga produk dan jasa }\end{array}$ & $\begin{array}{l}\text { STRATEGI ST } \\
\text { - Menjalin hubungan baik antar stakeholders } \\
\text { - Pengadaan papan informasi bencana } \\
\text { dan jalur evakuasi }\end{array}$ & $\begin{array}{l}\text { STRATEGI WT } \\
\text { - Meningkatkan kualitas kebersihan } \\
\text { - Menyesuaikan harga produk dan jasa dengan } \\
\text { kualitas pelayanan. } \\
\text { - Penyelesaian masalah ketersediaan air bersih }\end{array}$ \\
\hline
\end{tabular}

Sumber: Peneliti, 2019

\section{Strategi Pengembangan SO (Strengths-Opportunities)}

Strategi pengembangan SO disusun untuk memaksimalkan seluruh kekuatan yang dimiliki DTW Pantai Diamond dengan memanfaatkan peluang sebesarbesarnya. Hasil analisisi Matriks SWOT menghasilkan enam Strategi SO yang dapat diterapkan di DTW Pantai Diamond. 
Strategi SO-1. Menambah fasilitas photo spot. Memanfaatkan trend perkembangan jaman (memanfaatkan era digitalisasi modern) merupakan salah satu cara yang tepat untuk menarik lebih banyak wisatawan sekaligus melakukan promosi wisata.

Strategi SO-2. Mengembangkan fasilitas kepariwisataan. Pengembangan fasilitas di DTW Pantai Diamond harus saling terpadu antara peraturan kebijakan yang berlaku dengan model pengembangan yang akan dilaksanakan tanpa mengesampingkan sistem sosial masyarakatnya. Sebab, pengembangan fasilitas bertujuan untuk membawa keadaan sosial dan ekonomi masyarakat Dusun Pelilit menjadi lebih baik.

Strategi SO-3. Meningkatkan kualitas infrastruktur dan akses. Lokasi yang dapat dijangkau dengan menggunakan kendaraan bermotor serta didukung oleh baiknya kondisi infrastruktur menuju DTW Pantai Diamond akan mempermudah wisatawan untuk mengakses DTW tersebut.

Strategi SO-4. Melakukan promosi produk wisata. Mempromosikan produk pariwisata merupakan salah satu peluang yang saat ini belum dilakukan oleh pihak pengelola DTW Pantai Diamond. Oleh sebab itu, upaya yang dapat dilakukan oleh pengelola untuk meningkatkan jumlah kunjungan wisatawan adalah dengan memanfaatkan era digitalisasi sebagai pilihan promosi wisata, menyusun paket wisata yang menarik, serta menjalin kerja sama dengan berbagai agen perjalanan.

Strategi SO-5. Melakukan sosialisasi dan membentuk Pokdarwis. Perkembangagn industri pariwisata di Nusa Penida dirasa cukup pesat dan sangat mengejutkan bagi masyarakatnya. Masyarakat dipaksa menerima kehadiran wisatawan tanpa memahami tugas dan tanggungjawabnya sebagai pelaku industri pariwisata. Ketidaktahuan masyarakat ini akhirnya memaksa mereka untuk menerima kehadiran industri pariwisata dan bertindak sesuai dengan perilaku keseharian mereka, berdasarkan pada apa yang mereka ketahui dan bukan berdasarkan pada apa yang seharusnya dilakukan. Sosialisasi kebijakan adalah langkah yang harus dilakukan oleh pemerintah daerah maupun swasta untuk mengarahkan masyarakat 
dalam menjalankan industri pariwisata sesuai dengan peraturan yang berlaku, salah satu caranya adalah melalui pembentukan Pokdarwis.

Strategi SO-6. Menciptakan produk souvenir. Kain Tenun Rangrang merupakan salah satu hasil kerajinan masyarakat Dusun Pelilit yang dapat dikembangkan menjadi souvenir khas daerah. Dengan memberikan pengertian tentang makna modernisasi serta pelatihan ketrampilan kepada masyarakat tentang cara mengolah hasil kerajinan menjadi lebih modern, masyarakat akan dapat menghasilkan suatu barang yang unik dan menarik bagi wisatawan. Kemauan masyarakat untuk menyediakan produk khas daerah sebagai souvenir dapat dianggap sebagai salah satu wujud pelayanan masyarakat kepada wisatawannya. Terlebih lagi, apabila masyarakat juga bersedia untuk menunjukkan bagaimana proses pembuatan produk tersebut maka image tentang masyarakat yang pintar dan terampil dalam menghasilkan suatu produk tertentu akan terbentuk dalam benak wisatawan.

\section{Strategi Pengembangan WO (Weaknesses-Opportunities)}

Strategi pengembangan WO disusun untuk meminimalisir kelemahan melalui peluang yang dimiliki DTW Pantai Diamond. Hasil analisisi Matriks SWOT menghasilkan empat Strategi WO yang dapat diterapkan di DTW Pantai Diamond.

Strategi WO-1. Memaksimalkan ragam jenis atraksi wisata. Kualitas pemandangan alam DTW Pantai Diamond yang memperlihatkan tiga gugus karang berbentuk "diamond" atau permata telah dikenal oleh wisatawan maupun masyarakat lokalnya. Akan tetapi, DTW Pantai Diamond sebenarnya tidak hanya memiliki keindahan alam berupa tiga gugus karang saja, melainkan juga memiliki potensi kebudayaan daerah yang sebenarnya dapat dikelola menjadi daya tarik wisata, yakni Tari Jangkang dan Kain Tenun Rangrang.

Strategi WO-2. Menonjolkan arsitektur tradisional Bali. Warung makan di Bukit Diamond yang didirikan pada tahun 2015 telah mengadopsi prinsip arsitektur tradisional Bali, akan tetapi tidak pada warung makan di Pantai Diamond yang 
didirikan pada tahun 2018. Prinsip kedudukan dan susunan proporsional bagianbagian bangunan arsitektur tradisional Bali adalah memiliki bagian kaki (pondasi), badan (dinding) dan kepala (atap); menggunakan ornamen khas Bali yang telah dianggap milik Bali; serta menggunakan bahan/material lokal yang ada di sekitarnya.

Strategi WO-3. Memberikan pelatihan kepada SDM Pariwisata. Kualitas lingkungan, sosial budaya dan ekonomi akan terus menjadi pertimbangan calon wisatawan dalam menentukan lokasi tujuan wisatanya, sehingga ketiga unsur tersebut harus dijaga agar industri pariwisata tidak menurunkan kualitasnya. Antisipasi terhadap kemungkinan dampak yang disebabkan oleh aktivitas pariwisata akan menunjukkan kepedulian pengelola terhadap berbagai potensi yang dimanfaatkan sebagai daya tariknya. Upaya yang dapat dilakukan untuk meningkatkan kompetensi SDM dalam mengelola DTW dengan baik dan bijaksana adalah melalui pelatihan.

Strategi WO-4. Meningkatkan faktor keselamatan. Kestabilan struktur tebing DTW Pantai Diamond merupakan sebuah kelebihan tersendiri yang telah disediakan oleh alam pada saat pengelola akan mengembangkan suatu fasilitas kepariwisataan dengan memanfaatkan area tebing. Selain dapat meminimalkan biaya pembangunan, stabilitas tebing ini secara tidak langsung akan meningkatkan nilai keselamatan bagi wisatawannya. Meskipun demikian, pengelola tetap harus mengantisipasi kecelakaan yang suatu saat dapat terjadi pada siapapun yang berkunjung ke DTW Pantai Diamond.

\section{Strategi Pengembangan ST (Strengths-Threats)}

Strategi pengembangan ST disusun untuk meminimalisir ancaman dengan memaksimalkan kekuatan yang dimiliki DTW Pantai Diamond. Hasil analisisi Matriks SWOT menghasilkan dua Strategi ST yang dapat diterapkan di DTW Pantai Diamond. 
Strategi ST-1. Menjalin hubungan baik antar stakeholders. Kerja sama antar stakeholders akan memunculkan sifat saling membutuhkan dan menghargai antara stakeholder satu dengan lainnya. Melalui kerjasama yang baik antara pengelola, pemilik kawasan serta seluruh masyarakat lokal, akan memunculkan rasa keterikatan yang saling menguntungkan dan saling menghormati, dimana apabila dipelihara akan berdampak positif terhadap sektor ekonomi daerah dan meningkatkan kesejahtaraan masyarakat lokal di sekitar kawasan wisata. Stakeholders yang tidak memiliki pola pikir sama akan menghambat bahkan menggagalkan rencana pengembangan suatu kawasan wisata.

Strategi ST-2. Penyelesaian masalah ketersediaan air bersih. Masalah ketersediaan air bersih merupakan masalah terpelik yang masih dihadapi oleh beberapa wilayah di Pulau Nusa Penida, termasuk di Desa Pejukutan. Kondisi kelangkaan air ini dapat menghambat atau bahkan menggagalkan proses pengembangan kawasan apabila tidak diselesaikan sesegera mungkin. Upaya yang dapat dilakukan untuk menunjang kelancaran dan kesuksesan proses pengembangan kawasan adalah dengan membangun cubang (sumur yang digunakan oleh kebanyakan masyarakat Nusa Penida untuk menyimpan cadangan air pada saat musim kemarau panjang tiba) di beberapa titik kawasan, menambah sumur air bersih di area pura (rawa), serta melakukan aktivitas pembelian air.

\section{Strategi Pengembangan WT (Weaknesse-Threats)}

Strategi pengembangan WT disusun untuk meminimalkan kelemahan serta menghindari ancaman yang dimiliki DTW Pantai Diamond. Hasil analisisi Matriks SWOT menghasilkan dua Strategi WT yang dapat diterapkan di DTW Pantai Diamond.

Strategi WT-1. Meningkatkan kualitas kebersihan. Indikator kualitas kebersihan DTW Pantai Diamond telah mendapatkan penilaian baik dari wisatawan, hal tersebut disebabkan karena beberapa permasalahan-permasalahan kecil yang ada- 
seperti jumlah sampah yang belum begitu banyak serta aktivitas pembakaran sampah-mungkin belum nampak dan masih luput dari penilaian wisatawan. Akan tetapi, permasalahan-permasalahan kecil tersebut harus segera dikelola dengan baik agar tidak menjadi masalah besar yang dapat mengancam kesuksesan rencana pengembangan DTW Pantai Diamond dimasa akan datang.

Strategi WT-2. Menyesuaikan harga produk dan jasa dengan kualitas pelayanan. Upaya yang dapat dilakukan oleh pengelola DTW Pantai Diamond untuk menyesuaikan harga produk dan jasa dengan kualitas pelayanan yang diberikan adalah dengan memperbaiki kualitas infrastruktur, akses dan bentuk fisik fasilitas kepariwisataan; meningkatkan kompetensi SDM Pariwisata melalui pelatihan serta training skill (terkhusus dalam hal penguasaan bahasa asing); menerapkan SKKNI sebagai acuan dalam menyediakan SDM Pariwisata; serta mengharuskan pemilik usaha dan SDM Pariwisata memiliki sertifikasi ketenagakerjaan secara sah.

\section{Simpulan dan Saran}

Persepsi wisatawan terhadap komponen DTW Pantai Diamond secara keseluruhan adalah baik, dengan rata-rata penilaian tertinggi wisatawan adalah pada komponen citra, dan rata-rata penilaian terendah wisatawan adalah pada komponen aksesibilitas.Persepsi masyarakat terhadap pengembangan yang telah dilakukan di DTW Pantai Diamond adalah sangat baik untuk komponen atraksi; baik untuk komponen citra dan harga; serta buruk untuk komponen amenitas, aksesibilitas dan SDM.

Grand strategy pengembangan yang tepat berdasarkan faktor internal dan eksternal DTW Pantai Diamond adalah growth and stability (pelihara dan pertahankan) dan dapat dilaksanakan melalui tujuh poin strategi pengembangan, yakni memaksimalkan ragam jenis atraksi wisata baik wisata alam, seni, maupun budaya; menambah dan mengembangkan fasilitas kepariwisataan yang menonjolkan arsitektur tradisional Bali, menciptakan produk souvenir, serta 
menyelesaikan masalah ketersediaan air bersih; meningkatkan kualitas infrastruktur dan akses; meningkatkan faktor keselamatan dan kebersihan lingkungan; menjalin hubungan baik antar stakeholders, membentuk Pokdarwis, melakukan pelatihan dan sosialisasi kepada SDM Pariwisata serta masyarakat; menyesuaikan harga produk dan jasa dengan kualitas pelayanan yang diberikan; serta melakukan promosi produk wisata melalui media digital serta bekerjasama dengan agen perjalanan.

Saran kepada pihak pemerintah Desa Pejukutan secara khusus dan Kecamatan Nusa Penida secara umum adalah memperbaiki beberapa titik jalan rusak serta membentuk Pokdarwis untuk mengarahkan masyarakat maupun pengelola melalui sosialisasi.Saran kepada pihak pengembang adalah mengembangkan DTW berdasarkan peraturan dan kebijakan yang berlaku dan berasaskan pada konsep Triple Bottom Line serta blue ecomony agar tercipta sistem pariwisata yang berkelanjutan. Saran kepada pihak akademisi adalah melakukan penelitian lanjutan, baik mengenai dampak pengembangan pariwisata (ekonomi, sosial budaya, dan lingkungan), tingkat kepuasan wisatawan yang pernah berkunjung, maupun penelitian lainnya di DTW Pantai Diamond, Dusun Pelilit, sebagai penyempurna penelitain ini.Saran kepada pihak masyarakat adalah mewujudkan Sapta Pesona Pariwisata, yaitu menciptakan lingkungan pariwisata yang aman, tertib, bersih, sejuk, indah, ramah, dan kenangan, agar lingkungan lebih kondusif dan ideal bagi berkembangnya kegiatan kepariwisataan serta mendorong tumbuhnya minat wisatawan untuk berkunjung.

\section{Ucapan Terima Kasih}

Penulis menyampaikan ucapan terima kasih kepada Ir. A.A. Putu Agung Suryawan Wiranatha, M.Sc., Ph.D., selaku Pembimbing I, dan Dr. Ir. I Gusti Ayu Oka Suryawardani, M.Mgt., Ph.D., selaku Pembimbing II, dalam memberikan bimbingan selama penulisan tesis saat menempuh pendidikan di Program Studi Magister Kajian Pariwisata Universitas Udayana. Ucapan terima kasih juga disampaikan 
kepada Prof. Dr. Ir. Syamsul Alam Paturusi, MSP., Dr. I Nyoman Sukma Arida, M.Si., Gde Indra Bhaskara, M.Sc., Ph.D.selaku penguji tesis yang telah memberikan masukan dan saran. Penulis juga menyampaikan terima kasih kepada responden penelitian, teman-teman kuliah, staf sekretariat, dan keluarga yang telah mendukung penyusunan tesis dan artikel ini.

\section{Daftar Pustaka}

BPPT-HHBK, 2018. KHDTK Nusa Penida. [Online] Available at: http://balitbangtek-hhbk.org/2019/01/hutan-penelitian2/tampilkan

BPS Kabupaten Klungkung, 2016. Statistik Daerah Kecamatan Nusa Penida. Bali: BPS Kabupaten Klungkung.

BPS Kabupaten Klungkung, 2018. Kabupaten Klungkung Dalam Angka. Bali: BPS Kabupaten Klungkung.

BPS Kabupaten Klungkung, 2018. Kecamatan Nusa Penida Dalam Angka. Bali: BPS Kabupaten Klungkung.

Brooks, N., 2013. Triple Bottom Line - The Modern Business Model. [Online] Available at: http://www.powerhousegrowers.com/triple-bottom-line-themodern-business-model/

Chamdani, U., 2018. Indikator Strategi Pengembangan Kepariwisataan. Yogyakarta: CV Budi Utama.

David, F. R. \& David, F. R., 2017. Strategic Management (A competitive Advantage Approach Concepts and Cases). Sixteenth Edition (Global Edition) ed. British: Pearson.

Dewan Kelautan Indonesia, 2012. Kebijakan Ekonomi Kelautan dengan Model Ekonomi Biru, Jakarta: Kementrian Kelautan dan Perikanan.

Hill, A. V., 2016. Penta-Helix: Stakeholder Management For Complex Projects. [Online] Available at: https://medium.com/@adrianvhill/penta-helix-stakeholdermanagement-for-complex-projects-5bfea8d43be9

Pemerintah Kabupaten Klungkung, 2013. Peraturan Daerah Kabupaten Klungkung Nomor 1 Tahun 2013 Tentang Rencana Tata Ruang Wilayah Kabupaten Klungkung Tahun 2013-2033, Samarapura: Sekretaris Daerah Kabupaten Klungkung. 
Noordien,

A.

n.d.

Teori

Persepsi.

[Online]

Available

at:

https://www.academia.edu/6123394/Teori persepsi

[Accessed 10 Oktober 2019].

Pemerintah Kabupaten Klungkung, 2012. Rencana Pengelolaan KKP Nusa Penida, Kabupaten Klungkung, Propinsi Bali, Klungkung: Sekretaris Daerah Kabupaten Klungkung.

Pemerintah Kabupaten Klungkung, 2014. Peraturan Daerah Kabupaten Klungkung No.

7 Tahun 2014 Tentang Pengelolaan Sampah, Samarapura: Sekretaris Daerah Kabupaten Klungkung.

Pemerintah Republik Indonesia, 2009. Undang-Undang Republik Indonesia Nomor 10 Tahun 2009 Tentang Kepariwisataan, Jakarta: Sekretariat Negara RI.

Pemerintah Republik Indonesia, 2011. Lampiran II Peraturan Pemerintah Republik Indonesia Nomor 50 Tahun 2011 Tentang Rencana Induk Pembangunan Kepariwisataan Nasional Tahun 2010-2025, Jakarta: Kementrian Sekretariat Negara RI.

Rani, D. P. M., 2014. Pengembangan Potensi Pariwisata Kabupaten Sumenep, Madura, Jawa Timur (Studi Kasus: Pantai Lombang). Jurnal Politik Muda, Vol. 3 No. 3, pp. 412 - 421.

Rosyidah, N. A., 2017. Analisis pengungkapan Triple Bottom Line dan Faktor Yang Mempengaruhi. Jurnal Equity, Vol. 3, Issue 4, pp. 1 - 17.

Santhyasa, I. K. G., n.d. Problematika Pengelolaan Lingkungan Dan Keruangan Pariwisata Di Desa Lembongan, Bali. Denpasar, http://digilib.mercubuana.ac.id/manager/t!@file_artikel_abstrak/Isi_Artikel_786 623794614.pdf, pp. 241-246.

Sugiyono, 2013. Metode Penelitian Pendidikan (Pendekatan Kuantitatif, Kualitatif, dan R $\mathcal{E} D)$. Bandung: CV. Alfabeta.

Sunaryo, B., 2013. Kebijakan Pembangunan Destinasi Pariwisata (Konsep dan Aplikasinya di Indonesia). Yogyakarta: Gava Media.

Yulianti, W., n.d. Perkembangan Pariwisata di Bali. [Online] Available at: https://www.academia.edu/16006954/Perkembangan Pariwisata di Bali [Accessed 3 September 2019].

Zaenuri, M., 2012. Perencanaan Strategis Kepariwisataan Daerah: Konsep dan Aplikasi. Jogjakarta: e-Gov Publishing. 


\section{Profil Penulis}

Agnela Saneta Listiowati menyelesaikan studi strata satu Program Studi Teknik Arsitektur Fakultas Teknik Universitas Atma Jaya Yogyakarta pada tahun 2011. Pada tahun 2019, penulis menyelesaikan studi di Program Studi Magister Pariwisata Fakultas Pariwisata Universitas Udayana. Di dunia profesional, penulis berprofesi sebagai arsitek senior pada sebuah perusahaan konsultan desain yang menangani perencanaan berbagai proyek, baik desain interior maupun eksterior. Beberapa karya yang telah dihasilkan oleh penulis adalah Interior dan Eksterior Desain Pusat Pendidikan Taman Pintar Yogyakarta, Interior Desain Museum Paviliun V Akademi Militer Magelang, Interior dan Eksterior Desain Pengembangan Rumah Sakit Umum Temanggung, Interior dan Eksterior Desain Mall Malioboro Yogyakarta, Interior dan Eksterior Desain Hotel Ibis Yogyakarta, Interior dan Eksterior Hotel Novotel Yogyakarta, serta beberapa karya lainnya.

Ir. Anak Agung Putu Agung Suryawan Wiranatha, Msc., Ph.D merupakan Dosen pada Program Studi Magister Pariwisaata yang menyelesaikan pendidikan S1 di Institut Pertanian Bogor, S2 di Griffith University, Australia dan S3 di The University of Queensland, Australia. Bidang keahlian yang ditekuni adalah Perencanaan dan Pengembangan Pariwisata, Pariwisata Berkelanjutan dan Permodelan Sistem Pariwisata.

Dr. Ir. I Gusti Ayu Oka Suryawardani, M.Mgt., Ph.D merupakan Dosen yang saat ini menjabat sebagai Ketua Program Studi Magister Pariwisata yang menyelesaikan pendidikan S1 di Fakultas Pertanian Universitas Udayana, S2 di Faculty of Economic Business and Law, The University of Queensland, Brisbane Autsralia dan S3 Double Degree Indonesia Prancis: Unud - Paris 1 Pantheon Sorbonne, Paris, France. Bidang keahlian yang ditekuni adalah Consumen Behaviour, Tourism Economics and Tourism Marketing dan Permodelan Sistem Pariwisata. 